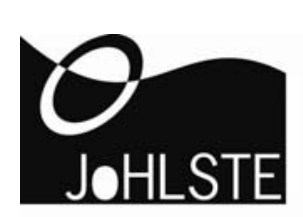

Journal of Hospitality, Leisure,

Sport \& Tourism Education

Vol. 6, No. 2.

ISSN: $1473-8376$

www.heacademy.ac.uk/hlst/resources/johlste

ACADEMIC PAPER

\title{
Service Quality in Higher Education: The Experience of Overseas Students
}

\author{
Maria Pereda (deceased) \\ David Airey (d.airey@surrey.ac.uk) and Marion Bennett (m.bennett@surrey.ac.uk) \\ Faculty of Management and Law, University of Surrey, Guildford GU2 7XH \\ (C) Journal of Hospitality, Leisure, Sport and Tourism Education
}

\begin{abstract}
The higher education of students has become increasingly internationalised, with an evergrowing proportion of students originating from overseas. However, research to date suggests that overseas students are often less satisfied with their courses than other students. Consequently, there is a burgeoning need for universities to understand what students value in their university experience. This paper reports on a study that establishes and tests dimensions for measuring service quality in higher education, focusing on full-feepaying postgraduate students from non-EU countries at one institution in the UK. The institution concerned has a particular reputation in tourism and hospitality and a significant proportion of the respondents were studying these subjects. Adopting Lehtinen and Lehtinen's 1991 framework, a Q-sort was undertaken followed by factor analysis. The results of the research highlighted four factors of service quality: recognition; quality of instruction and interaction with faculty; sufficiency of resources; and aspects of physical quality. Arguably, the most significant finding here is the importance that these students attach to their institution's reputation.
\end{abstract}

Keywords: Service quality; Higher education; International students

Maria Pereda died in May 2006 shortly after completing her PhD thesis. The degree was awarded posthumously. A native of Venezuela, Maria graduated from Venezuela Central University and held an appointment at Simon Bolivar University in Caracas. She completed her MSc at the University of Surrey in 2000, focusing on tourism and hospitality education. This paper is based on her PhD research.

David Airey is Professor of Tourism Management and Pro-Vice-Chancellor at the University of Surrey. He has spent 30 years involved in tourism education in various capacities: with government, with the European Commission and with universities. He is co-editor, with John Tribe, of the recently published International Handbook of Tourism Education.

Marion Bennett is Associate Lecturer in Tourism and Marketing at the University of Surrey. She has held lecturer positions since 1991 with the Universities of Strathclyde and Surrey, where her interests have focused on information technology and marketing in relation to tourism distribution, heritage and air transport. 


\section{Introduction}

The education of full-fee-paying international students has become of major importance for universities in Western nations, particularly in major English speaking destination countries. Barron (2005: 353) has suggested that "international education is one of Australia's largest industries" and that the fees generated by international students are important to the budgetary health of institutions. In the UK, according to HESA (2006) and UKCOSA (2004), about 320,000 or 13 per cent of students in 2004-2005 came from overseas, with about 10 per cent from outside the European Union (EU). This figure more than doubled from about 160,000 in 1994-1995. For some institutions, international students currently represent more than 25 per cent of their student population (UKCOSA, 2006). The main countries of domicile of international students in the UK are China (32,000 or 12 per cent) and Greece ( 9 per cent), with at least a further 20 countries each providing more than 2,500 students. As far as tourism is concerned, equivalent total figures (UCAS, 2006) suggest that overseas students represent about 16 per cent of acceptances onto programmes, rising from 11 per cent in 1996. Clearly this level of enrolment has represented a major opportunity for institutions, particularly at a time when public funding for higher education has been constrained; but it has also presented challenges. Barron (2005: 355) has pointed to the extent to which most universities have designated international departments responsible for marketing and recruitment, but goes on to highlight the need to ensure that such students are properly supported after arrival, providing evidence to suggest that this does not always happen, leading to frustration and disappointment. A recent report by the Higher Education Policy Institute (Bekhradnia et al., 2006) confirms this, suggesting that non-EU overseas respondents were considerably less satisfied than others with the value for money received on their course.

Against this background, it is clearly important for universities to understand what students value in their university experience, including those from overseas. It has been common practice for many years for higher education institutions to provide opportunities for students to evaluate their learning and teaching experience, typically in the form of end-of-semester or end-of-course evaluations. Many institutions also gain feedback from students about services such as the library or computing. A recent addition to these information sources in the UK has been the National Student Survey (NSS), which focuses on learning and teaching experiences. However, surveys of the overall experience or overall quality have been more rare (Aldridge and Rowley, 1998).

This paper reports on a study (Pereda, 2006) that was designed to establish and test dimensions for measuring service quality in higher education, with specific reference to students following postgraduate taught programmes for master degrees, over one year, from countries outside the EU. Many of these were following programmes in tourism and hospitality. Specifically, the study aimed to identify from the literature three dimensions of service quality (physical, interactive and corporative), which were then validated with a Qsort. This provided the basis for a survey of 330 students at one institution in the UK, designed to measure their views of the quality of service received. This provides insights into the items that students value in their educational experience at this institution. It also provides a basis for redefining the dimensions of service quality.

\section{Service quality for international students}

The migration of international students is by no means a new phenomenon. Schachner (1962: 25), for example, refers to the students in medieval times who "poured in an increasing flood to the centres where they could literally sit at the feet of the great teachers and absorb wisdom". To some extent, the search for knowledge remains an important driver for international movement in education today, but, in other ways, motives, influences and indeed origin and destination countries have changed radically. During the most recent and biggest expansion of international education, the USA, UK and Australia have become the main destination countries and the countries of South East Asia have joined those of Europe as large providers of students. The search for knowledge has been joined by a range of other 
factors in driving this growth. These include: the marketing campaigns of receiver universities; the perceived value of a foreign degree in terms of employment enhancement or 'snob value'; the absence of sufficient university places at home; government policy in relation to student fees; and more extraneous factors such as opportunities for emigration (Pereda, 2006). As far as individual institutions are concerned, Allen and Higgins (1994), from a study of 82 institutions in the UK, report that the most important factors for international students when selecting a university were academic reputation, course content and entry requirements. But perhaps the biggest change, driven in part by the need for Western universities to maintain numbers of international students, particularly where these pay full tuition fees, has been the recognition of such students as an important 'market' that needs to be satisfied in an increasingly competitive world. Wright and O'Neill (2002), for example, point to the extent to which an assessment of students' perspectives has become a crucial requirement if universities are to remain competitive. More than 20 years ago, Glisan (1984) highlighted the special interest in overseas students, while Mortimer (1997) emphasised the need to examine and understand the decision-making process undertaken by these students and for institutions to respond to their needs.

To this extent, universities have become increasingly involved in defining service quality and measuring customer satisfaction in ways that are familiar to service marketing specialists (Gronroos, 1984; Kotler, 1985), who themselves were developing measures of service quality from the 1980s. As noted by Patterson et al. (1998) and Conant et al. (1985), the most important customers, namely students and their parents, and the university providers have progressively changed towards a customer service orientation. Against this background, there has been a rapid expansion in the literature about this aspect of service quality. However, the way in which it has typically developed - by identifying the attributes from consultation with the students and then evaluating these (Bourke, 1997; Gatfield et al., 1999; Joseph, 1998; Thompson and Thompson, 1996) - has meant that there has been a great diversity and lack of consistency in methodological strategies and in the variables employed to assess the service quality (Leonard et al., 2003). Some researchers in education have used SERVQUAL, which is the most popular model to measure service quality, sometimes specifically adapted for the education sector (Wright and O'Neill, 2002; Gatfield, 2000). Orr (2000) identified five groups of organisational determinants of success in the provision of fee-paying graduate courses. Pate (1993) split the literature on student satisfaction into three perspectives: psychological-wellness-type satisfaction (related to personal characteristics); job-type satisfaction (related to future aspirations); and consumertype satisfaction (related to daily experience). However, the general picture is of a profusion and indeed a confusion of measured variables, some replicated across different studies, others unique to a particular study.

In an initial attempt to understand the underlying patterns of service quality variables from these previous studies in higher education, a framework proposed by Lehtinen and Lehtinen (1991) was used. The framework was considered to offer a useful preliminary way to structure information relating to education as a service. Lehtinen and Lehtinen separately identified three dimensions of service quality: the physical quality (both products and support); the interactive quality (interaction between consumer and service provider); and the corporative quality (the image). Using these three dimensions, some 24 studies specifically related to quality in higher education were reviewed to establish whether these dimensions could be identified from the variables considered in earlier studies of higher education. For a dimension to exist it had to be included in more than three studies (Ekinci and Riley, 2001).

The results and the studies are given in Table 1. From this it is clear that the physical quality dimension (general services, teaching and learning facilities, accommodation) and the interactive quality dimension (academic instruction, guidance, interaction with staff and students) are well included in the existing studies. The corporative quality dimension (recognition, reputation, value for money) is also present, but is less fully covered and mainly appears in papers concerned with marketing orientation (Bourke, 1995; Wilkinson, 1993). 
Pereda, Airey and Bennett (2007) Service Quality in Overseas Education: The Experience of Overseas Students

\begin{tabular}{l|c|c|c}
\hline \hline Study (author year) & Physical quality & Interactive quality & Corporative quality \\
\hline Mavondo et al., 2004 & $\mathrm{X}$ & $\mathrm{X}$ & $\mathrm{X}$ \\
Wiers-Jenssen, 2003 & $\mathrm{X}$ & $\mathrm{X}$ & \\
Wright and O'Neill, 2002 & $\mathrm{X}$ & $\mathrm{X}$ & \\
Elliot and Shin, 2002 & $\mathrm{X}$ & $\mathrm{X}$ & $\mathrm{X}$ \\
Wiers-Jenssen et al., 2002 & $\mathrm{X}$ & $\mathrm{X}$ & $\mathrm{X}$ \\
Clemes et al., 2001 & $\mathrm{X}$ & $\mathrm{X}$ & \\
Gatfield, 2000 & $\mathrm{X}$ & $\mathrm{X}$ \\
Oldfield and Baron, 2000 & $\mathrm{X}$ & $\mathrm{X}$ & $\mathrm{X}$ \\
Gatfield et al., 1999 & $\mathrm{X}$ & $\mathrm{X}$ & \\
Ford et al., 1999 & $\mathrm{X}$ & $\mathrm{X}$ & $\mathrm{X}$ \\
Patterson et al., 1998 & $\mathrm{X}$ & $\mathrm{X}$ & \\
Joseph, 1998 & $\mathrm{X}$ & $\mathrm{X}$ & \\
Aldridge and Rowley, 1998 & $\mathrm{X}$ & $\mathrm{X}$ & $\mathrm{X}$ \\
Athiyaman, 1997 & $\mathrm{X}$ & $\mathrm{X}$ & \\
Bourke, 1997 & $\mathrm{X}$ & $\mathrm{X}$ & \\
Tomkovick et al., 1996 & $\mathrm{X}$ & $\mathrm{X}$ & \\
Soutar and McNeil, 1996 & $\mathrm{X}$ & $\mathrm{X}$ & \\
Rogers and Smith, 1993 & $\mathrm{X}$ & $\mathrm{X}$ & \\
Hampton, 1993 & $\mathrm{X}$ & $\mathrm{X}$ & \\
Lapidus and Brown, 1993 & $\mathbf{2 2}$ & \\
Stewart, 1991 & $\mathrm{X}$ & \\
Ortinau et al., 1989 & Xolcyn, 1986 & & \\
\hline
\end{tabular}

Table 1: Higher Education Evaluation Matrix

Physical quality - general services, teaching and learning facilities, accommodation Interactive quality - academic instruction, guidance, interaction with staff and students Corporative quality - recognition, reputation, value for money

This study focused specifically on students from non-EU countries following postgraduate taught programmes. The fact that they are both international and postgraduate identifies them as a particular segment of the student market, and, as noted, it is one that has been showing significant growth and fee-earning potential. In many ways, their needs and responses are similar to those of other students but in significant ways they are also different. For example, as international students, the 2004 study by UKCOSA (2004) indicated that both postgraduates and undergraduates showed high levels of satisfaction with their academic experience (87 per cent), although, at 91 per cent, the undergraduates were rather more positive than their postgraduate counterparts at 85 per cent. This broad similarity is reflected in the other items included in the UKCOSA survey, with a notable exception that, at 85 per cent, undergraduates were more likely than postgraduates (65 per cent) to be offered university housing at the beginning of their stay. Other differences identified in the literature (Pereda, 2006) are that postgraduates are likely already to have been exposed to academic life, are older, with more work experience and experience of living independently. International students have similar issues to their domestic counterparts but additionally they face some specific issues, the most commonly cited being knowledge of English, inadequate financial resources, social adjustment, problems of daily living, loneliness and homesickness (Kennedy, 1995; Wilkinson, 1993; Burns, 1991; Samuelowicz, 1987). These, combined with the fact that they, or their families, are normally paying full fees, may partly explain the extent to which they are more critical of their experience and more demanding (Pereda, 2006). The study by the Higher Education Policy Institute (Bekhradnia et al., 2006) relating to English 
universities showed that nearly 30 per cent of such students found their courses represented poor value for money compared with 15 per cent of home and EU students. The fact that this study relates to this particular segment provides information about an important group, but the extent to which the results can be related to all international students or to students in general needs to be tempered by these differences.

\section{Methodology}

Having reached a point of identifying from the literature the ingredients of and preliminary structure for service quality in higher education, the research strategy was developed to identify statements and dimensions that would capture the students' experiences of service quality and to measure these at a particular institution with a large cohort of international students. The students included in the survey were all from non-EU countries taking taught master degree courses, typically over one year, in different aspects of management.

Admittedly, this approach contains limitations, being confined to particular students studying a particular group of courses at one institution. The advantage of this approach was partly one of convenience and logistics, but also that it permitted the identification of a sufficiently large and coherent group of students with roughly similar experiences, hence avoiding differences between institutions, subjects, ages and experience.

The institution concerned is based in the South of England and achieved university status in the 1960s. It has a strong research reputation as well as strong links with the world of work. Specifically for this study it has a long-standing and strong international reputation for hospitality and tourism education. It regularly ranks as one of the leading centres both for teaching and research in these areas, and is one of only two institutions in the UK accredited by the UN World Tourism Organisation. It has a developing reputation for other management programmes, with recent accreditations by the American body, the Association to Advance Collegiate Schools of Business (AACSB) and the Association of MBAs (AMBA), placing it among leading business schools. For more than 20 years it has attracted a large number of international students, and currently more than 90 per cent of its postgraduate students in management are from outside the UK. A dedicated international office provides specific support for these international students.

The fieldwork was organised into two main parts. First, a Q-sort was used to establish the validity of the three dimensions and to establish statements related to the dimensions. A selection of these statements was then used both to explore the response of international students to their experience and to conduct an exploratory factor analysis, which ultimately identified four factors of service quality.

Q-technique has its origins in the work of Stephenson (1935; 1953) and provides researchers with a systematic and orderly means for identifying the dimensions of subjective phenomena from the viewpoints and experiences of individuals. In brief, it attempts to convert subjective responses into measurable dimensions, which can then be formally evaluated by statistical applications. To this extent it is a preliminary method. It makes the study of human subjectivity amenable to 'objective analysis', hence combining the strengths of both quantitative and qualitative research (Sexton et al., 1998). This versatile procedure is well suited to cases where the existence of concepts has not been established (Ekinci and Riley, 2001). The evaluation of students' experiences comes into this category and was used here as a first step. Stergiou (2004) had earlier, and for similar reasons, followed this approach in relation to students' views about teaching.

The Q-sort was carried out in two phases. In the first phase, a bank of statements was created to represent the dimensions suggested by Lehtinen and Lehtinen (1991). The initial set of statements was generated from previous questionnaires in the area of higher education, including unpublished dissertations (Leonard et al., 2003), as well as from discussions with researchers in related areas. An initial pilot test was conducted with five subjects in order to check the instructions and any wording problems with the statements that 
were generated. For the first Q-sort, a total of 104 statements were used, related to physical quality (34 statements), interactive quality (38 statements) and corporative quality (32 statements). Respondents for the study were confined to students enrolled in a postgraduate programme at the researchers' university for at least one semester. The experience in the university is a basic requirement to evaluate the service. The Q-sort was completed by a total of 30 students from 28 different countries, including two from the UK, six from other EU countries and 22 from other parts of the world. These students were asked to sort the statements, which had been printed onto separate cards, into the three dimensions and then, for each group of statements, to classify them into: 'most important' (the kind of service you would expect to have); 'least important'; and 'not relevant'. In order to qualify, a statement needed to be allocated to the same heading by at least 60 per cent of the sample (Ekinci and Riley, 2001; Hinkin and Schriesheim, 1989) and a minimum of four qualified statements was required to validate the existence of a dimension. The result of this Q-sort was a set of 85 validated statements distributed as follows: physical quality 38; interactive quality 29; corporative quality 18 .

For the second Q-sort, in order to have a better balanced representation among the three dimensions, the best 20 statements that obtained a degree of consensus of 70 per cent or more were used for the first two dimensions, physical quality and interactive quality. However, further adjustments were also made both to avoid omitting likely determinants of student satisfaction - for example, library services - and to remove statements that essentially had the same meaning. For corporative quality, which only achieved 18 validated statements, three of which did not reach the cut-off of 70 per cent, five new statements were added. Hence, the second Q-sort took place with 60 statements, 20 related to each dimension. The respondents for this second round were 30 non-British full-fee-paying students enrolled on PhD (12) and master (18) degree programmes in different departments of the university. They were asked to sort the cards in the same way as in the first Q-sort. The output from this round was a set of 59 validated statements. One item was rejected from corporative quality.

The second stage of the study involved further exploration of the statements to establish how they impacted on student views of the quality of service provided and how well they confirmed the existence of the three dimensions. For this, a research instrument was implemented with students taking taught postgraduate master level programmes at the institution. The final response was from 330 students taking a range of programmes in management and related areas. Eighty-four of these were on programmes related to hospitality and tourism, although it should be noted that this underestimates such students because a number of them identified themselves as studying 'management', omitting to mention their particular specialism. All were overseas students paying full fees. The research instrument was distributed personally in spring 2005, in most cases at the end of classes, and self-completed in the researcher's presence. Forty statements in total were used from the second Q-sort to measure student views of the quality of service. Fifteen of these related to physical quality, 11 to interactive quality and 14 to corporative quality. The statements are given in Table 2.

\begin{tabular}{l|l|l}
\hline \hline Physical quality & Mean & SD \\
\hline \hline The gardens and open areas on the campus are kept clean & 5.22 & 1.17 \\
\hline Students' rooms are provided with adequate internet connections & 5.14 & 1.90 \\
\hline The classrooms have up-to-date teaching support equipment & 5.10 & 1.05 \\
\hline The university has modern computers with the latest programmes & 5.06 & 1.30 \\
\hline Student accommodation is safe & 4.66 & 1.31 \\
\hline The university has sufficient residential accommodation & 4.66 & 1.41 \\
\hline The library has a wide range of book and periodicals in my area of studies & 4.57 & 1.51 \\
\hline The rooms in the student residential accommodation are comfortable & 4.55 & 1.28 \\
\hline
\end{tabular}


Pereda, Airey and Bennett (2007) Service Quality in Overseas Education: The Experience of Overseas Students

\begin{tabular}{|c|c|c|}
\hline Adequate printer facilities are available & 4.43 & 1.38 \\
\hline The campus computers are sufficient for the student population & 4.31 & 1.41 \\
\hline $\begin{array}{l}\text { The communal areas in each student residence are adequate for the number } \\
\text { of students }\end{array}$ & 4.29 & 1.45 \\
\hline The university has plenty of sports facilities & 4.20 & 1.36 \\
\hline The sport centre offers modern equipment & 4.17 & 1.32 \\
\hline The university offers modern accommodation at affordable prices & 3.94 & 1.33 \\
\hline The university provides adequate parking areas for students & 3.70 & 1.48 \\
\hline \multicolumn{3}{|l|}{ Interactive quality } \\
\hline My course is intellectually challenging & 5.02 & 1.04 \\
\hline Staff react politely to students' queries & 4.71 & 1.19 \\
\hline It is easy to make friends on campus & 4.70 & 1.23 \\
\hline The administrative staff are helpful & 4.60 & 1.32 \\
\hline Lecturers stimulate critical analysis & 4.56 & 1.19 \\
\hline There are clear and reasonable requirements for each module & 4.55 & 1.10 \\
\hline Lecturers can be easily contacted individually & 4.48 & 1.19 \\
\hline It is easy to get involved in campus social organisations & 4.35 & 1.28 \\
\hline Lecturers have adequate time for consultation & 4.28 & 1.22 \\
\hline Feedback from coursework is adequate & 4.23 & 1.12 \\
\hline It is easy to interact with local students & 3.62 & 1.50 \\
\hline \multicolumn{3}{|l|}{ Corporative quality } \\
\hline The university takes the lead in research & 4.85 & 1.04 \\
\hline A degree from this university improves my employment prospects & 4.85 & 1.02 \\
\hline The university maintains links with international education networks & 4.70 & 1.16 \\
\hline A degree from this university is well recognised internationally & 4.69 & 1.14 \\
\hline The university is well recognised for the academic programmes & 4.66 & 1.20 \\
\hline The university offers a high quality of teaching performance & 4.57 & 1.17 \\
\hline The ranking of my school is high & 4.57 & 1.32 \\
\hline $\begin{array}{l}\text { Graduates from this university achieve considerable success in finding } \\
\text { excellent employment }\end{array}$ & 4.45 & 1.20 \\
\hline A degree from this university has an excellent reputation in my home country & 4.32 & 1.38 \\
\hline The university maintains excellent links with local industry & 4.23 & 1.33 \\
\hline The university has contacts with international employers & 4.18 & 1.29 \\
\hline $\begin{array}{l}\text { The university has been extensively recommended by my friends in my home } \\
\text { country }\end{array}$ & 3.92 & 1.37 \\
\hline Lecturers in my home country recommended this university to me & 3.84 & 1.48 \\
\hline There are excellent links between my home country and this university & 3.45 & 1.30 \\
\hline
\end{tabular}

Table 2: Students' views of the quality of service provided

$7=$ strongly agree; $1=$ strongly disagree

A seven-point Likert scale was used for this purpose, and respondents were asked to indicate the extent to which they agreed or disagreed with the statements relating to their experience. The instrument also collected data on satisfaction, value for money and demographics. These are not reported here.

The analysis included the preparation of descriptive statistics, cross-tabulations against various independent variables, and exploratory factor analysis with Varimax rotation. An 
Pereda, Airey and Bennett (2007) Service Quality in Overseas Education: The Experience of Overseas Students

overall Cronbach alpha coefficient of .875, results from more than 300 respondents, a Kaiser-Meyer-Olkin measure of sampling adequacy of more than .60 and the Bartlett's test results all gave support that the set of data was adequate for factor analysis, with a factor loading of .35.

\section{Results and discussion}

The students' views on the quality of service provided under the three dimensions are given in Table 2. These, together with the reasons for enrolling in the particular programme presented in Table 3, provide an indication of the elements of service quality that are of importance to these international students. The reputation and content, including the English language provision, of the programme are clearly important to the students in making their decisions about where to study.

\begin{tabular}{l|l}
\hline \hline Reason & No $(\mathbf{n}=\mathbf{3 0 8})$ \\
\hline \hline Degree accepted internationally & 184 \\
\hline English language spoken & 152 \\
\hline Content of the course & 142 \\
\hline Reputation of this university back home & 103 \\
\hline Facilities & 91 \\
\hline Entry requirement & 63 \\
\hline Getting an offer of a place & 62 \\
\hline Influence of friends/family & 54 \\
\hline Know someone studying there & 52 \\
\hline Degree not available at home & 52 \\
\hline Scholarship award & 42 \\
\hline Sponsor's decision & 19 \\
\hline Level of fees & 13 \\
\hline Difficulty of getting into university at home & 11 \\
\hline
\end{tabular}

Table 3: Reasons for enrolling

The most important finding of the research to be reported here was that the factor analysis did not entirely support the structure proposed by Lehtinen and Lehtinen. Indeed, as set out in Table 4, four dimensions are identified, and of these, Factor 1 is by far the most important, accounting for the largest proportion of the variance (34 per cent), with eigenvalues greater than 3.00 (6.156). This factor includes a group of statements related to research, rigour and reputation, and is labelled here 'recognition'.

\begin{tabular}{|c|c|c|c|c|}
\hline & \multicolumn{4}{|c|}{ Factors } \\
\hline & 1 & 2 & 3 & 4 \\
\hline \multicolumn{5}{|l|}{ Factor 1: recognition } \\
\hline The ranking of my school is high (corporative quality) & .772 & & & \\
\hline $\begin{array}{l}\text { A degree from this university is well recognised } \\
\text { internationally (corporative quality) }\end{array}$ & .702 & & & \\
\hline The university takes the lead in research (corporative quality) & .659 & & & \\
\hline $\begin{array}{l}\text { A degree from this university has an excellent reputation in } \\
\text { my home country (corporative quality) }\end{array}$ & .652 & & & \\
\hline My course is intellectually challenging (interactive quality) & .609 & & & \\
\hline \multicolumn{5}{|l|}{ Factor 2: quality of instruction and interaction with faculty } \\
\hline $\begin{array}{l}\text { Lecturers have adequate time for consultation (interactive } \\
\text { quality) }\end{array}$ & & .765 & & \\
\hline
\end{tabular}




\begin{tabular}{|c|c|c|c|c|}
\hline $\begin{array}{l}\text { Lecturers can be easily contacted individually (interactive } \\
\text { quality) }\end{array}$ & & .758 & & \\
\hline $\begin{array}{l}\text { There are clear and reasonable requirements for each } \\
\text { module (interactive quality) }\end{array}$ & & .663 & & \\
\hline Lecturers stimulate critical analysis (interactive quality) & & .611 & & \\
\hline Feedback from coursework is adequate (interactive quality) & & .454 & & \\
\hline \multicolumn{5}{|l|}{ Factor 3: sufficiency of resources } \\
\hline $\begin{array}{l}\text { The campus computers are sufficient for the student } \\
\text { population (physical quality) }\end{array}$ & & & .724 & \\
\hline Adequate printer facilities are available (physical quality) & & & .689 & \\
\hline $\begin{array}{l}\text { The communal areas in each student residence are } \\
\text { adequate for the number of students (physical quality) }\end{array}$ & & & .657 & \\
\hline $\begin{array}{l}\text { The university has sufficient residential accommodation } \\
\text { (physical quality) }\end{array}$ & & & .642 & \\
\hline \multicolumn{5}{|l|}{ Factor 4: quality of facilities } \\
\hline The university has plenty of sport facilities (physical quality) & & & & .863 \\
\hline The sports centre has modern equipment (physical quality) & & & & .802 \\
\hline $\begin{array}{l}\text { The classrooms have up-to-date teaching support equipment } \\
\text { (physical quality) }\end{array}$ & & & & .526 \\
\hline $\begin{array}{l}\text { The gardens and open areas on campus are kept clean } \\
\text { (physical quality) }\end{array}$ & & & & .483 \\
\hline Eigenvalue & 6.156 & 1.527 & 1.375 & 1.272 \\
\hline Explained variance by factor (\%) & 34.199 & 8.481 & 7.640 & 7.069 \\
\hline
\end{tabular}

Table 4: Service quality scale: factor loading structure

Extraction method: principle component analysis.

Rotation method: Varimax with Kaiser Normalisation. Rotation converged in five iterations

To some extent this reflects how the university positions itself as a demanding and competitive body. The other three factors did not reach eigenvalues of 3.00 , and the percentage variance together only accounts for 23 per cent of the total. The second factor roughly relates to Lehtinen and Lehtinen's 'interactive quality' and here is labelled 'quality of instruction and interaction with faculty'. The items here emphasise the importance of the lecturer in his or her intrinsic role as a teacher, willing to guide, teach and motivate students. The variables included in this factor also provide evidence of the responsibilities of the lecturer towards the students in terms of providing clear instructions, accurate and punctual feedback and private consultation. Factor 3 includes four items from 'physical quality', and although they only explain 7.64 per cent of the common variance, all the items have high loadings, ranging from .642 to .724 . Interestingly, they all relate to the adequate provision of services by the university and hence are labelled here 'sufficiency of resources'. The last factor, although composed of four items from 'physical quality', does not show a clear pattern - two of the items refer to sport facilities (both of which have high loadings), the modernity of classroom facilities and cleanliness of the campus.

This recasting of the dimensions provides an interesting step in translating service quality thinking into the arena of higher education. In particular, it emphasises the point that the provision of services is not only about the actual facilities (classrooms, computers, etc) and the ways in which they are delivered (by the teachers), both of which find correspondence in any service; it also highlights the fact that there is another, in this case overriding, dimension for students in the ways in which they judge their institution. This is the standing or recognition of the university, which in itself is a combination of achievements often over many years in the wide range of activities covered by universities - teaching, research, invention and knowledge creation. In the case of this particular study, this may be partly explained by the fact that the institution concerned has an outstanding and long-established reputation for 
tourism and hospitality studies, and a significant proportion of the respondents were taking these programmes. In the same way, ancient universities, some with histories over many centuries, offer 'reputation' as a key element in attracting students. This 'recognition' dimension, of course, also finds expression in other services and goods, but arguably its explanatory strength for universities in distinguishing between institutions, particularly for overseas students, is more powerful than in other areas.

It is difficult to generalise from this to all universities. Given the rapid expansion of the sector in recent years, there has been little time for many institutions to have developed their reputations. This may explain why in earlier studies (Gatfield et al., 1999; Tomkovick et al., 1996) which have included 'reputation' it has not consistently appeared as the most important factor. Indeed, 'academic instruction' has more typically explained most of the variance (Gatfield, 2000; Elliot and Shin, 2002; Patterson et al., 1998). However, what it does point to potentially is the sheer importance of reputation once it has been achieved and, as a corollary, the imperative to maintain reputation. Against this background, league tables and world rankings take on a crucial role and hence become a vital part of the development and survival strategy for institutions in an increasingly competitive world. As international recruitment and international competition in higher education increases, this is likely to figure increasingly prominently in the strategies of universities.

\section{Conclusion}

Three important issues come out of this work in relation to the things that students value in their university experience. First, in line with previous studies, the evaluation of higher education includes a complex and diverse range of variables, from classroom experience to library and computing provision, from social and sporting activities to international recognition. Second, the work in measuring service quality provides a good starting point for understanding the basic structure of the variables that students take into account in evaluating their experience. And third, there is, at least for some universities, including the one where the study took place, a fourth dimension related to reputation; in this case, a reputation in hospitality and tourism may have influenced the results. This then points to a key feature of higher education provision, which is that universities are not a uniform range of institutions. They vary enormously by, for example, age, size, structure, specialism and orientation, and any form of evaluation will be likely to reflect these differences. In this case, it is reputation and recognition that has come through. In other universities and with other student groups there may well be other dimensions in the variables.

This study was based on one institution and sought the views of the international, postgraduate, full-fee-paying students who had already taken a decision about where to study, and the configuration of the variables reflects this. Primarily, it has brought the reputation of the institution into prominence; but it has also provided a further basis for understanding the issues that international students value. Given the likely continued growth in international student movements, there are key lessons here for institutions, not least in the importance of developing and maintaining reputation. As already noted, in an environment of globalisation, international competition and league tables, reputation is likely to increase in importance.

Of course, given the sample of a particular group of students studying particular subjects at one institution, there are some important limitations in the extent to which it is possible to generalise the results. However, notwithstanding this weakness, both the approach and the findings in terms of the key variables and dimensions provide pointers to approaches to understanding the views of students and the ways in which this important group of students view their experience.

There are clearly many further avenues for research in this area. A wider range of institutions with different priorities, a wider range of subject areas and coverage of undergraduate and domestic students would all provide further insights to the views of students about their 
Pereda, Airey and Bennett (2007) Service Quality in Overseas Education: The Experience of Overseas Students

experiences and about the dimensions that they value. But perhaps most important for tourism and hospitality specialists would be a specific focus on students studying these subjects. While they are a significant cohort among the students included in the survey, and this study can provide pointers, their number was not sufficient to draw final conclusions about their particular characteristics, if any. This work remains to be done.

\section{References}

Aldridge, S. and Rowley, J. (1998) Measuring Customers' Satisfaction in Higher Education. Quality Assurance in Education, 6, 197-204.

Allen, A. and Higgins, T. (1994) Higher Education: The International Student Experience. Leeds: HEIST.

Athiyaman, A. (1997) Linking Student Satisfaction and Service Quality Perceptions: the case of university education. European Journal of Marketing, 31, 528-540.

Barron, P. (2005) Cultural Issues in Learning. In: D. Airey and J. Tribe (eds.) An International Handbook of Tourism Education. Oxford: Elsevier, 353-366.

Bekhradnia, B., Whitnall, C. and Sastry, T. (2006) The Academic Experience of Students in English Universities. London: Higher Education Policy Institute.

Bourke, A. (1995) A Model of the Determinants of International Trade in Higher Education. Service Industries Journal, 20.

Bourke, A. (1997) The Internationalisation of Higher Education. Higher Education Quarterly, 51, 325-346.

Burns, R. (1991) Study and Stress among First Year Overseas Students in an Australian University. Higher Education Research and Development, 10, 61-77.

Clemes, M., Ozanne, L. and Tram, L. (2001) An Examination of Students' Perceptions of Service Quality in Higher Education. Journal of Marketing for Higher Education, 10, 1-19.

Conant, J., Brown, J. and Mokwa, M. (1985) Students are Important Consumers: assessing satisfaction in a higher education context. Journal of Marketing Education, 7(2) 13-20.

Ekinci, Y. and Riley, M. (2001) Validating Quality Dimensions. Annals of Tourism Research, 28, 201-223.

Elliot, K. and Shin, D. (2002) Student Satisfaction: an alternative approach to assessing this important concept. Journal of Higher Education Policy and Management, 24, 197-209.

Ford, J., Joseph, M. and Joseph, B. (1999) Importance-Performance Analysis as a Strategic Tool for Service Marketers: the case of service quality perceptions of business students in New Zealand. The Journal of Services Marketing, 13, 171-186.

Gatfield, T. (2000) A Scale for Measuring Student Perception of Quality: an Australian Asian perspective. Journal of Marketing for Higher Education, 10, 27-41.

Gatfield, T., Bakker, M. and Graham, P. (1999) Measuring Student Quality Variables and the Implications for Management Practices in Higher Education Institutions: an Australian and international perspective. Journal of Higher Education and Management, 21, 239-252.

Glisan, G. (1984) A Marketing Approach to Student Evaluation of a Department of Marketing. Journal of Higher Education, 54, 159-163.

Gronroos, C. (1984) A Service Quality Model and its Marketing Implications. European Journal of Marketing, 18, 139-150.

Hampton, G. (1993) College Students' Satisfaction: marketing's approach for evaluating higher education. Journal of Professional Services Marketing, 9, 115-128.

HESA (2006) Higher Education Statistics for the United Kingdom 2004-05. Cheltenham: Higher Education Statistics Agency.

Hinkin, T. and Schriesheim, C. (1989) Development and Application of New Scales to Measure the French and Raven Bases of Social Power. Journal of Applied Psychology, 74, 561-567.

Joseph, M. (1998) Determinants of Service Quality in Education: a New Zealand perspective. Journal of Professional Services Marketing, 16, 43-71.

Kennedy, K. (1995) Developing a Curriculum Guarantee for Overseas Students. Higher Education Research and Development, 14, 35-46.

Kotler, P. (1985) Strategic Marketing for Educational Institutions. London: Prentice-Hall. 
Pereda, Airey and Bennett (2007) Service Quality in Overseas Education: The Experience of Overseas Students

Lapidus, R. and Brown, J. (1993) Assessing Satisfaction with the University Experience: an international perspective. Journal of Consumer Satisfaction, Dissatisfaction and Complaining Behaviour, 6, 187-192.

Lehtinen, U. and Lehtinen, J. (1991) Two Approaches to Service Quality Dimensions. The Service Industries Journal, 11, 287-303.

Leonard, D., Pelletier, C. and Morley, L. (2003) The Experiences of International Students in UK Higher Education: A Review of Unpublished Research. London: UKCOSA.

Mavondo, F., Tsarenki, Y. and Gale, T. (2004) International and Local Student Satisfaction: resources and capabilities perspective. Journal of Marketing for Higher Education, 14, 4160.

Mortimer, K. (1997) Recruiting Overseas Undergraduate Students: are their information requirements being satisfied? Higher Education Quarterly, 51, 225-238.

Oldfield, B. and Baron, S. (2000) Student Perceptions of Service Quality in a UK University Business and Management Faculty. Quality Assurance in Education, 8, 85-95.

Orr, S. (2000) The Organisational Determinants of Success for Delivering Fee-Paying Graduate Courses. The International Journal of Educational Management, 14, 54-61.

Ortinau, D., Bush, A. J., Bush, R. P. and Twible, J. (1989) The Use of Importance Performance Analysis for Improving the Quality of Marketing Education: interpreting faculty-course evaluation. Journal of Marketing Education, 11(2), 78-86.

Pate, W. (1993) Consumer Satisfaction, Determinants and Post-Purchase Actions in Higher Education. College and University Journal, 68, 100-107.

Patterson, P., Romm, T. and Hill, C. (1998) Consumer Satisfaction as a Process: a qualitative, retrospective longitudinal study of overseas students in Australia. Journal of Professional Services Marketing, 16, 135-157.

Pereda, M. (2006) An Examination of the Impact of Service Quality Dimensions on Students' Satisfaction in Higher Education in the UK. Thesis, (PhD). University of Surrey.

Polcyn, L. (1986) A Two-Instrument Approach to Student Satisfaction. College and University Journal, 62, 18-24.

Rogers, A. and Smith, P. (1993) Identifying the Needs of Overseas Students: a monitoring exercise at the University of Southampton. Journal of International Education, 3, 7-24.

Samuelowicz, K. (1987) Learning Problems of Overseas Students: the two sides of a story. Higher Education Research and Development, 6, 121-133.

Schachner, N. (1962) The Medieval Universities. New York: A. S. Barness and Co.

Sexton, D., Snyder, P., Wadsworth, D., Jardine, A. and Ernest, J. (1998) Applying Q Methodology to Investigations of Subjective Judgements of Early Intervention Effectiveness. Topics in Early Childhood Special Education, 18, 95-107.

Soutar, G. and McNeil, M. (1996) Measuring Service Quality in a Tertiary Institution. Journal of Educational Administration, 34, 72-82.

Stephenson, W. (1935) Correlating Persons instead of Tests. Character and Personality, 4, 17-24.

Stephenson, W. (1953) The Study of Behaviour: Q-technique and its Methodology. Chicago: University of Chicago Press.

Stergiou, D. (2004) Knowledge and Teaching: an investigation on what makes good teaching in tourism higher education. Thesis, (PhD). University of Surrey.

Stewart, K. (1991) Applying and Marketing Orientation to a Higher Education Setting. Journal of Professional Services Marketing, 7, 117-124.

Thompson, H. and Thompson, G. (1996). Confronting Diversity Issues in the Classroom with Strategies to Improve Satisfaction and Retention of International Students. Journal of Education for Business, 72, 52-58.

Tomkovick, C., Al-khatib, J., Badawaj, B. and Jones, S. (1996) An Assessment of the Service Quality Provided to Foreign Students at US Business Schools. Journal of Education for Business, 71, 130-135.

UCAS (2006) Universities and Colleges Admissions Service Statistics. Available from: http://www.ucas.com/figures/index.html

UKCOSA (2004) Broadening our Horizons: International Students in UK Universities and Colleges. Report of the UKCOSA Survey. London: UKCOSA, The Council for International Education. 
Pereda, Airey and Bennett (2007) Service Quality in Overseas Education: The Experience of Overseas Students

UKCOSA (2006) Higher Education Statistics. Available from: http://ww.ukcosa.org.uk/pages/hestats.htm

Wiers-Jenssen, J. (2003) Norwegian Students Abroad: experiences of students from a linguistically and geographically peripheral European Country. Studies in Higher Education, 28, 391-411.

Wiers-Jenssen, J., Stensaker, B. and Grogaard, J. (2002) Student Satisfaction: towards an empirical deconstruction of the concept. Quality in Higher Education, 8, 183-195.

Wilkinson, J. (1993) Marketing Australian Universities to Overseas Students. Australian Marketing Journal, 1, 71-79.

Wright, C. and O'Neill, M. (2002) Service Quality Evaluation in the Higher Education Sector: an empirical investigation of students' perceptions. Higher Education Research and Development, 21, 23-39. 